\title{
Accidental head injury in childhood
}

\author{
D. L. JAMISON* and H. H. KAYE \\ From the Children's Department, Newcastle General Hospital, Newcastle upon Tyne
}

\begin{abstract}
Jamison, D. L., and Kaye, H. H. (1974). Archives of Disease in Childhood, 49, 376. Accidental head injury in childhood. Over a 2-year period 857 children were admitted to hospital with head injuries, representing $16 \%$ of all admissions$73 \%$ of all children with injury-and occupying 3727 bed-days. Operation was required in $6 \%$ of cases, $1.5 \%$ were left with residual neurological deficit, and $1.5 \%$ died. The epidemiology is presented in detail and it is noted that $66 \%$ of admissions occurred when medical and ancillary staff on immediate duty were limited. A more selective approach to the timing and taking of skull $x$-rays is urged. The retention of British Standard Time (one hour fast on G.M.T., darker mornings) through the winter did not increase the number of admissions due to head injury.
\end{abstract}

Head injury is the most common form of trauma for which children are admitted to hospital (Rickham, 1961), and is therefore likely to reflect any change in the general incidence of accidents. Study of the epidemiology of accidents is necessary before any planned attempt at accident prevention is made. In this study particular attention has been paid to the time of the accident and an attempt has been made to relate this to hospital staffing conditions. An inquiry is made into the greater accident liability alleged to have been created by the prolongation of British Standard Time in 1968 (Daily Telegraph, 1970).

\section{Method and patients}

Newcastle General Hospital includes the Regional Neurological Centre which serves a child population estimated at 800,000 (Digest of Health Statistics, 1971), and most children with injuries are admitted to the children's department of the hospital. Between 28 October 1967 and 27 October 1969, 1179 children were admitted as a result of trauma and 857 of these were included in the study. Children were included if they had received a blow on the head with external evidence of injury or with a history of impaired consciousness. Simple lacerations of the scalp without loss of consciousness or other neurological symptoms and signs were excluded. 12 infants with nonaccidental injuries (battered babies) were also excluded. Cases transferred from other hospitals were included only if admitted within 24 hours of the accident. Information about each patient was obtained from case notes.

Received 1 October 1973.

^Present address: The Hospital for Sick Children, Great Ormond

\section{Results}

During the 2-year period 5385 children were admitted to hospital, the 857 with head injuries accounting for $16 \%$ of the total admissions and for $73 \%$ of children admitted with injuries. Only 10 (1\%) had previously been admitted for injury.

Age, sex, and social class (Registrar General, 1971). The maximum frequency was between 6 and 7 years of age, the prevalence in boys becoming greater after the age of 3 years (Fig. 1). Overall there was a male/female ratio of $2 \cdot 12 / 1$. The distribution of cases according to social class is shown in Table I. The control group consists of

TABLE I

Social class

\begin{tabular}{c|c|c}
\hline \multirow{2}{*}{ Social class } & \multicolumn{2}{|c|}{ Percentage of total } \\
\cline { 2 - 3 } & Head injuries & Controls \\
\hline I & $1 \cdot 5$ & $3 \cdot 0$ \\
II & $10 \cdot 5$ & $11 \cdot 0$ \\
III & $26 \cdot 5$ & $29 \cdot 0$ \\
IV & $35 \cdot 0$ & 32.0 \\
V & 26.5 & $25 \cdot 0$ \\
\hline
\end{tabular}

468 consecutive admissions to the children's wards over a period of 6 months. We were unable to detect any significant relation between social class distribution and the incidence of admission to hospital for head injury. 


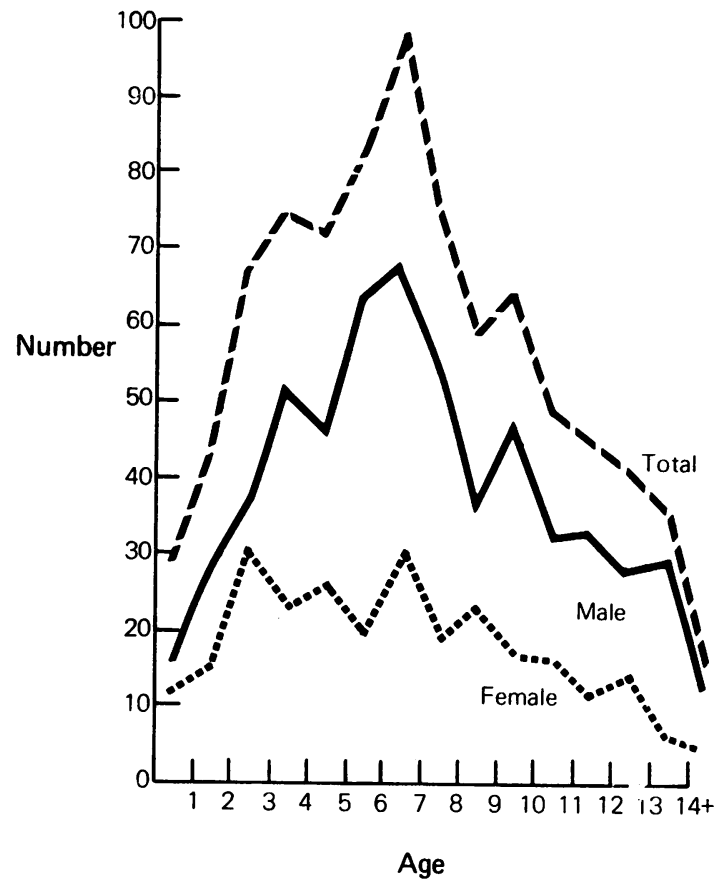

FIG. 1.-Distribution of cases of head injury according to age and sex.

Time of accident and hospital admission. Most accidents occurred between 15.00 and 19.00 hours when school was closed. During the summer the high incidence continued until 20.00 hours, and in winter the number of accidents fell after 17.00 hours. Head injuries were more common in summer (307) than in winter (117).

Only two head injuries were admitted as a result of accidents occurring in the extra darkness created by the continuance of British Standard Time into the winter of 1968/9. One of them was sustained indoors and the other occurred outside but in a domestic situation. No road traffic accidents occurring during this period of the day resulted in head injury admissions.

The most common time for admission to hospital (Fig. 2) was between 19.00 and 21.00 hours. A few patients were transferred from other hospitals because of signs related to the use of mydriatics or anticonvulsants. Most children stayed in hospital between 24 and 48 hours, but 80 were in for more than one week and 12 stayed in longer than one month. The 857 patients occupied 3727 bed-days in the 2-year period.

Nature and place of accident (Fig. 3 and 4). Younger children appear to be injured more

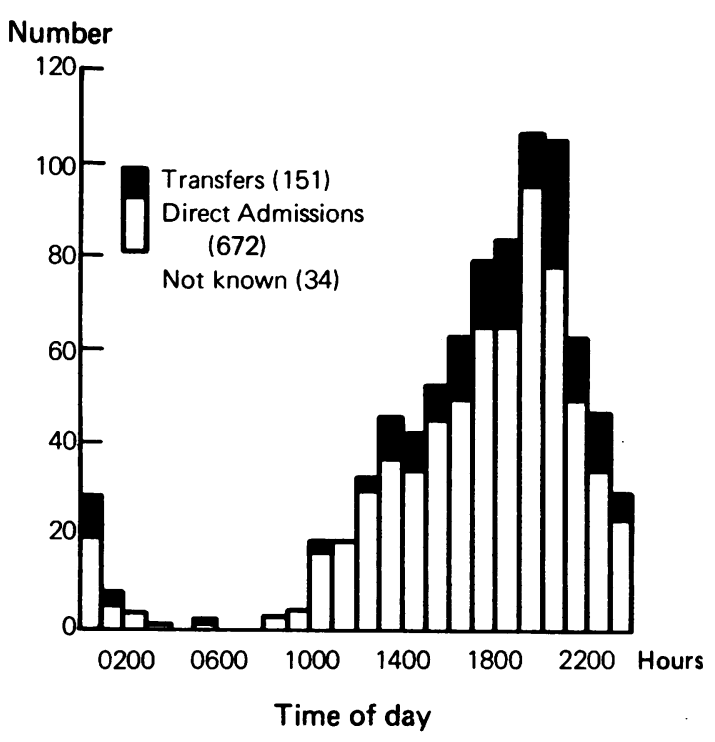

FIG. 2.-Time of admission to hospital.

commonly indoors and older children outdoors. Once competence at bicycle riding is achieved, children seem just as likely to fall off whatever their age. Prominent among indoor accidents were falls down stairs (4\% of all admissions) and out of windows (5\%); whereas outdoor accidents were caused by falls from walls (5\%) and roofs (3\%). Some of these occurred in derelict buildings. In the recreation area falls from slides, swings, and trees predominated.

Road traffic accidents involved 280 children (33\%) and the majority were pedestrians, 5 being associated with ice cream vans. 83 children (30\%) were in the 5- to 8-year-old group, $63(22 \%)$ were in the preschool age group.

Symptoms and signs. Drowsiness (63\%) and vomiting $(55 \%)$ were the most common symptoms, a history of loss of consciousness being noted in only $36 \%$, headache in $30 \%$, and amnesia or confusion in $25 \%$. 42 children (5\%) had convulsions for the first time after their head injury. The incidence was the same in the under 5-year-old group as in the over 5-year-olds. 4 other children with convulsions had a previous history of epilepsy. Symptoms of ataxia were recorded in 17 cases (2\%). A transitory visual loss was complained of by 13 patients $(1.5 \%)$, another 10 had 'blurred vision', and 5 experienced transitory diplopia.

Impaired consciousness was found on admission in 251 children (29\%) (Fig. 5). Between 30 and 
Number
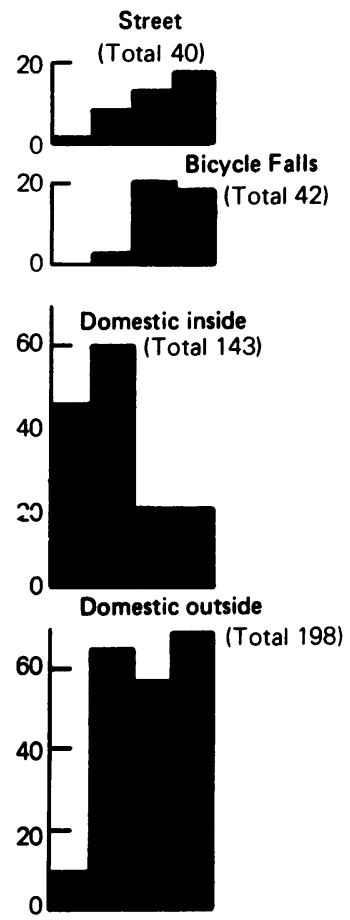

$\begin{array}{llll}0 & 11 / 2 & 5 & 8\end{array}$ Years

Age group
Number
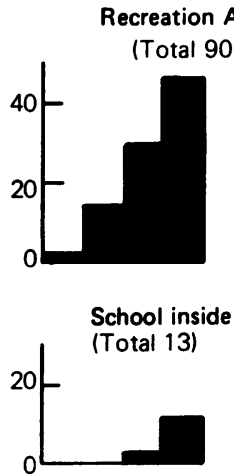

School outside

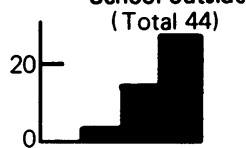

Not known

(Total 7)

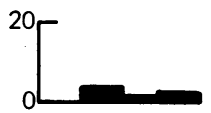

$\begin{array}{lllll}0 & 11 / 2 & 5 & 8 & \text { Years }\end{array}$

Age group

FIG. 3.-Site of accident (road traffic accidents excluded).

$34 \%$ of each age group were affected, except that in children under 18 months only $13 \%$ had impaired consciousness. $16 \%$ had other neurological signs which increased in incidence with age (Table II). Other injuries sustained included fractures, particularly of the long bones, extensive soft tissue

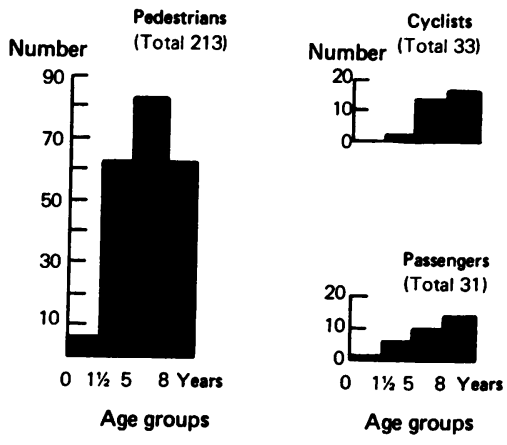

FIG. 4.-Road traffic accidents.

injuries, ruptured abdominal viscera, and pneumothorax.

TABLE II

Neurological signs

\begin{tabular}{l|c|c}
\hline \multicolumn{1}{c|}{ Total of 416 cases in 1 yr } & No. & $\%$ \\
\hline Extensor plantar response (over 18 & & \\
$\quad$ months of age) & 27 & 6 \\
Other pyramidal signs, e.g. hemiparesis & 17 & 4 \\
Pupillary abnormality (mydriatics & 7 & $1 \cdot 6$ \\
$\quad$ excluded) & 7 & $1 \cdot 6$ \\
Meningism & 2 & \\
Facial nerve palsy & 2 & \\
Photophobia & 1 & \\
Ataxia & 1 & \\
Dysphasia & \\
\hline
\end{tabular}

Radiology and surgery. The results of plain film examinations of the skull are summarized in Table III. 32 children (4\%) showed evidence of a

TABLE III

Skull radiology

\begin{tabular}{l|r|r}
\hline & No. & $\%$ \\
\hline No fracture seen & 612 & 72 \\
Unsuspected unrelated lesions & 0 & 0 \\
Linear fracture & 163 & 19 \\
Depressed fracture & 43 & 5 \\
Compound fracture & 10 & 1 \\
Total with fractures present & 216 & 25 \\
No films taken & 29 & 3 \\
\end{tabular}

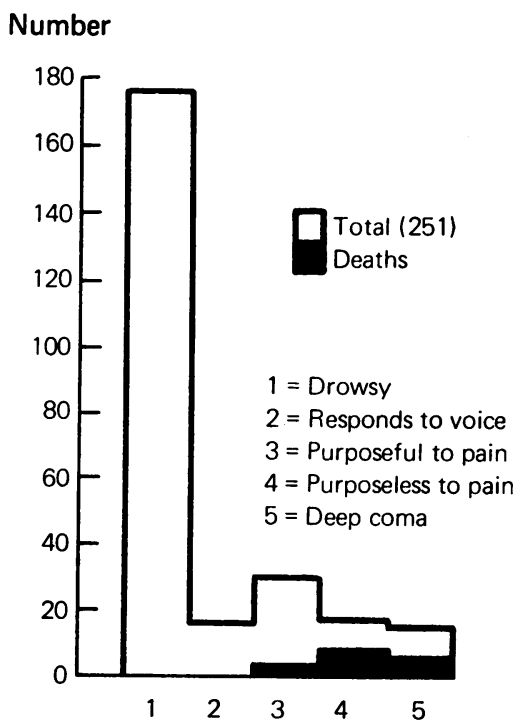

Fig. 5.-Depth of unconsciousness on admission to hospital. 
fracture involving the air sinuses or associated with an overlying laceration and were therefore treated as compound fractures. A further 27 cases were treated as compound fractures because of bleeding from inside the auditory meatus, though no fracture of the base of the skull had been seen on $x$-ray. Additional neuroradiology was performed in 14 cases $(1 \cdot 6 \%)$.

Excluding facial lacerations and minor scalp wounds, surgery to the head was performed in $\mathbf{5 1}$ patients $(6 \%)$. Those requiring operation to soft tissues numbered 15 (2\%), operation for fracture 15 $(2 \%)$, and 21 cases required operation because of evidence of raised intracranial pressure.

Ten cases had subdural $(1 \cdot 2 \%)$ and 4 had extradural haemorrhages, all of the latter surviving without handicap. Half of the cases with subdural haemorrhages died.

Residual sequelae and deaths (Tables IV and V). Apart from 2 children, residual sequelae were found only in patients who had sustained their original injuries in road traffic accidents. Over half of the deaths were pedestrians who were knocked over by motor vehicles. 10 of the 14 deaths occurred within 48 hours of admission.

\section{Discussion}

The fact that head injury is twice as common in boys as in girls has been shown in most previous surveys (Rowbotham et al., 1954; Burkinshaw, 1960; Partington, 1960; Read et al., 1963; Hendrick, Harwood-Hash, and Hudson, 1964; Klonoff and Robinson, 1967; Rune, 1970), and is probably due to the more adventurous spirit of older boys. Though it has been suggested that children admitted with head injury come from an accident-prone background (Hjern and Nylander, 1964), only $1 \%$ of our cases had been previously admitted for injury. This is comparable to Partington's figure of $1.6 \%$ (Partington, 1960).

The vulnerability of children to road accidents is influenced by factors such as crowding of the family, the availability of play facilities, and whether or not the mother is pregnant or goes out to work (Backett and Johnston, 1959), but we did not find that this was reflected in the social class distribution of our patients. Well over half the accidents occurred out of doors where children are less likely to be under direct parental supervision, and the high incidence of accidents in the street suggests a general lack of safe recreational facilities. The higher incidence of accidents in summer merely reflects the longer period of daylight after school when the majority of children sustained their injuries.

At the time when most children are admitted to hospital (19.00-21.00 hours) the ward is usually covered by the minimum number of junior staff, and their naturally cautious approach results in a smaller number of children being observed at home by their parents (Lewin, 1963). Many children are drowsy in the evening for a more common reason than their head injury - the approach of bedtime. 25 of our cases were discharged before 24 hours and probably fall within this category.

Two-thirds of admissions occurred when laboratory, radiography, and nursing staff were on a night basis, and as all but 3\% had plain film skull

TABLE IV

Sequelae

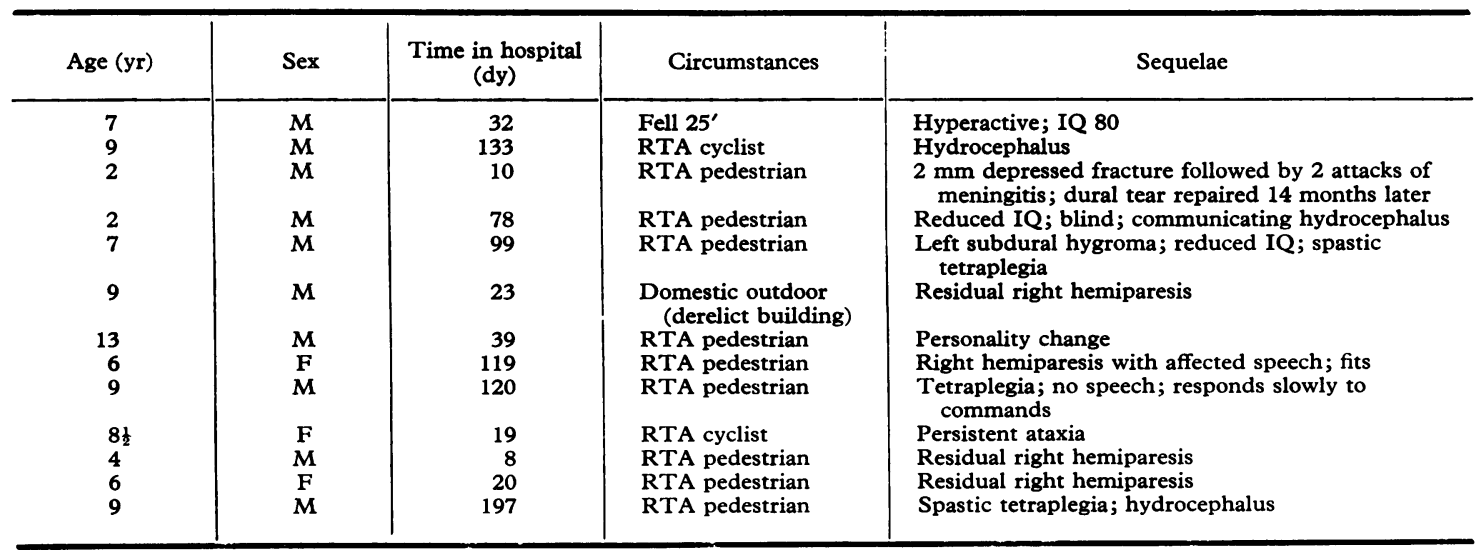


TABLE V

Deaths

\begin{tabular}{|c|c|c|c|c|c|c|c|}
\hline $\begin{array}{l}\text { Age } \\
(y \mathbf{r})\end{array}$ & $\operatorname{Sex}$ & Circumstances & $\begin{array}{c}\text { Depth of } \\
\text { unconsciousness }\end{array}$ & $\begin{array}{l}\text { Pupillary } \\
\text { abnormality }\end{array}$ & $\begin{array}{l}\text { Other } \\
\text { neurological } \\
\text { signs }\end{array}$ & $\begin{array}{l}\text { Time in } \\
\text { hospital } \\
\text { (dy) }\end{array}$ & Cause of death \\
\hline 5 & $\mathbf{F}$ & RTA pedestrian & 5 & - & 一 & 0 & $\begin{array}{l}\text { Ruptured liver and spleen; } \\
\text { subdural haematoma }\end{array}$ \\
\hline 4 & $\mathbf{F}$ & RTA pedestrian & 5 & + & - & 1 & $\begin{array}{l}\text { Bilateral subdurals (only one } \\
\text { side explored) }\end{array}$ \\
\hline 3 & $\mathbf{M}$ & RTA pedestrian & 4 & - & $\begin{array}{l}\text { Decerebrate } \\
\text { rigidity }\end{array}$ & 0 & Cerebral contusion \\
\hline 4 & $\mathbf{F}$ & Bannister fall & 5 & + & $\begin{array}{l}\text { Decerebrate } \\
\text { rigidity }\end{array}$ & 0 & Cerebral lacerations \\
\hline 2 & $\mathbf{F}$ & Window fall & 5 & + & Areflexia & 0 & Cerebral lacerations \\
\hline 11 & $\mathbf{M}$ & RTA pedestrian & 4 & + & $\begin{array}{l}\text { Areflexia, } \\
\text { periodic } \\
\text { breathing }\end{array}$ & 1 & $\begin{array}{l}\text { Cerebral oedema + bilateral } \\
\text { subdurals (drained) }\end{array}$ \\
\hline 11 & $\mathbf{F}$ & RTA pedestrian & 4 & + & Areflexia & 19 & Cerebral contusion \\
\hline 4 & $\mathbf{M}$ & RTA pedestrian & 4 & + & $\begin{array}{l}\text { Periodic } \\
\text { breathing }\end{array}$ & 4 & $\begin{array}{l}\text { Cerebral contusion (developed } \\
\text { hypernatraemia) }\end{array}$ \\
\hline 10 & $\mathbf{F}$ & $\begin{array}{l}\text { RTA car passenger } \\
\text { whiplash hitting } \\
\text { head on windscreen }\end{array}$ & 3 & - & $\begin{array}{l}\text { Transitory left } \\
\text { arm paresis }\end{array}$ & 5 & $\begin{array}{l}\text { Died } 40 \text { days later from } \\
\text { undiagnosed atlantoaxial } \\
\text { dislocation }\end{array}$ \\
\hline 9 & $\mathbf{F}$ & Slipped on rocks & 5 & + & Areflexia & 0 & $\begin{array}{l}\text { Cerebral contusion with } \\
\text { multiple skull fractures }\end{array}$ \\
\hline 10 & $\mathbf{M}$ & Tree fall & 4 & - & $\begin{array}{l}\text { Progressive } \\
\text { hemiparesis }\end{array}$ & 1 & $\begin{array}{l}\text { Lacerated swollen brain } \\
\text { (repaired dural tear) }\end{array}$ \\
\hline 3 & $\mathbf{M}$ & RTA pedestrian & 4 & + & $\begin{array}{l}\text { Decerebrate } \\
\text { rigidity }\end{array}$ & 0 & $\begin{array}{l}\text { Subdural (drained); } \\
\text { undiagnosed ruptured spleen }\end{array}$ \\
\hline 5 & $\mathbf{M}$ & RTA pedestrian & 4 & + & $\begin{array}{l}\text { Periodic } \\
\text { breathing }\end{array}$ & 1 & $\begin{array}{l}\text { Contused temporal lobes; } \\
\text { drained subdurals }\end{array}$ \\
\hline 6 & $\mathbf{M}$ & RTA pedestrian & 3 & - & $\begin{array}{l}\text { Hyperreflexia, } \\
\text { extensor } \\
\text { plantars }\end{array}$ & 5 & $\begin{array}{l}\text { Pulmonary haemorrhage, } \\
\text { ruptured liver and } \\
\text { suprarenal; pituitary necrosis }\end{array}$ \\
\hline
\end{tabular}

^For key, see Fig. 5. RTA, road traffic accident.

$x$-rays on admission, this resulted in a considerable work load. The radiology of head injury has been influenced for many years by 'medicolegal' factors (Burkinshaw, 1972; Bell and Loop, 1971), but in practice the need for urgent neurosurgical intervention is judged on clinical observation (Matson, 1961). A skull $x$-ray can be of value in the assessment of cases requiring less urgent operation such as depressed fractures, and the presence of an angulated bone fragment may lead to suspicion of a dural tear. A fracture should be looked for in all children with full thickness scalp injuries (Miller and Jennett, 1968) because of the need for antibiotic cover in these cases. There seems to be no reason, however, why some of these less urgent examinations should not be delayed until a time when more adequate facilities are available, at the same time allowing the important duty of observation to be uninterrupted (Roberts and Shopfner, 1972).

Windows and stairs are still dangerous places for children, especially the preschool group, and the number of pedestrians involved in road traffic accidents $(25 \%)$ emphasizes the vulnerability of children on the roads. This is especially so in the 5- to 8-year-olds (Hendrick et al., 1964; Bull, 1970), and may be due to the relative imbalance of strength and co-ordination at this age.

In Birmingham (MacKay, 1969) it was found that $5 / 9$ pedestrian traffic accident deaths occurred within 5 minutes of the accident so the 14 deaths after admission in this paper are 'late' deaths, though like Barr and Ralston's cases (1964), most occurred within 24 hours of admission. On admission they were characterized by coma and either areflexia or decerebrate rigidity. The importance of considering other injuries is shown by the children who died from an unrecognized ruptured spleen, a subdural haematoma on the unexplored side, and an atlantoaxial dislocation. At least half of the children with extradural haemorrhages would have died if there had been delay in the treatment. In the children reviewed by Harris (1957), 4/11 of those with extradural haematomata died because of delay in instituting therapy and, as in 2 of our cases, he noted a shorter history as compared with adults, often with no initial period of unconsciousness. One of our cases, like that reported by Lewin (1967), was apnoeic until the clot was removed. 3 of Harris's and one of our cases had no fracture on the $x$-ray, stressing the necessity for urgent operation 
rather than losing time $x$-raying these patients if they are deteriorating rapidly. The absence of a fracture in extradural haemorrhages occurring in younger patients has been emphasized recently by Galbraith (1973). Certainly children with head injuries requiring admission should be admitted to a unit where burr holes can be undertaken quickly.

Convulsions immediately associated with the injury occurred in 5\% of our cases as in Jennett's experience but, unlike Jennett (1972, 1973), we found that the incidence was the same in the under 5-year-olds as in older children. Transient blindness or an episode of blurred vision is not uncommon, occurring in 3\%. Griffith and Dodge (1968) reported 7 children and found it to be associated with EEG changes of bilateral occipital slowing, but recovery, as in our cases, was complete in all in a period from a few minutes to 3 or 4 hours.

Rowbotham et al. (1954), in a previous Newcastle series of $\mathbf{4 0 0}$ children, reported a death rate of $8.5 \%$ as compared with our $1.5 \%$ rate. This may reflect improved management (Lewin, 1967; MacIver et al., 1958), but Craft, Shaw, and Cartlidge (1972) reported a sixfold rise in Newcastle head injury admissions between 1950 and 1971, so these improving figures may be simply the result of more children with less severe head injuries being admitted.

We thank Dr. George Davison and his paediatric and neurosurgical colleagues at Newcastle General Hospital for the use of information about patients in their care. Our gratitude is also due to Miss R. Gordon and her helpers in the Medical Records Department.

\section{REFERENCES}

Backett, E. M., and Johnston, A. M. (1959). Social patterns of road accidents to children. British Medical fournal, 1, 409.

Barr, J. B., and Ralston, G. J. (1964). Head injuries in a peripheral hospital. Lancet, 2, 519.

Bell, R. S., and Loop, J. W. (1971). Utility and futility of radiographic skull examination for trauma. New England fournal of Medicine, 284, 236.

Bull, J. P. (1970). Epidemiology of road accidents. British fournal of Hospital Medicine, 4, 437.

Burkinshaw, J. (1960). Head injuries in children. Archives of Disease in Childhood, 35, 205.
Burkinshaw, J. (1972). Head injuries in children. British Medical fournal, $1,378$.

Craft, A. W., Shaw, D. A., and Cartlidge, N. E. F. (1972). Head injuries in children. British Medical fournal, 4, 200.

Daily Telegraph (1970). 13 July.

Digest of Health Statistics for England and Wales, p. 3. (1971). H.M.S.O., London.

Galbraith, S. L. (1973). Age-distribution of extradural haemorrhage without skull fracture. Lancet, 1, 1217.

Griffith, J. F., and Dodge, P. R. (1968). Transient blindness following head injury in children. New England fournal of Medicine, 278, 648.

Harris, P. (1957). Head injuries in childhood. Archives of Disease in Childhood, 32, 488.

Hendrick, E. B., Harwood-Hash, D. C. F., and Hudson, A. R. (1964). Head injuries in children: a survey of 4,465 consecutive cases at The Hospital for Sick Children, Toronto, Canada. Clinical Neurosurgery, 11, 46.

Hjern, B., and Nylander, I. (1964). Acute head injuries in children. Acta Paediatrica, 53, 90.

Jennett, B. (1972). Head injuries in children. Developmental Medicine and Child Neurology, 14, 137.

Jennett, B. (1973). Trauma as a cause of epilepsy in childhood. Developmental Medicine and Child Neurology, 15, 56.

Klonoff, H., and Robinson, G. C. (1967). Epidemiology of head injuries in children. Canadian Medical Association fournal, 96, 1308.

Lewin, W. S. (1963). Symposium on head injuries. B.M.A. Annual Clinical Meeting. British Medical fournal, 2, 1185.

Lewin, $W$. (1967). Severe head injuries. Proceedings of the Royal Society of Medicine, 60, 1208.

MacIver, I. N., Lassman, L. P., Thomson, C. W., and McLeod, I. (1958). Treatment of severe head injuries. Lancet, 2, 544.

MacKay, G. M. (1969). Some features of traffic accidents. British Medical fournal, 4, 799.

Matson, D. D. (1961). Craniocerebral trauma in childhood. American fournal of Surgery, 101, 677.

Miller, J. D., and Jennett, W. B. (1968). Complications of depressed skull fracture. Lancet, 2, 991.

Partington, M. W. (1960). The importance of accident-proneness in the aetiology of head injuries in childhood. Archives of Disease in Childhood, 35, 215.

Read, J. H., Bradley, E. J., Morison, J. D., Lewall, D., and Clarke, D. A. (1963). The epidemiology and prevention of traffic accidents involving child pedestrians. Canadian Medical Association fournal, 89, 687.

Registrar General (1971). Decennial Supplement, England and Wales, Occupational Mortality Tables. H.M.S.O., London.

Rickham, P. P. (1961). Head injuries in childhood. Helvetica Chirurgica Acta, 28, 560.

Roberts, F., and Shopfner, C. E. (1972). Plain skull roentgenograms in children with head trauma. American fournal of Roentgenology, 114, 230.

Rowbotham, G. F., Maciver, I. N., Dickson, J., and Bousfield, M. E. (1954). Analysis of 1,400 cases of acute injury to the head. British Medical fournal, 1, 726.

Rune, V. (1970). Acute head injuries in children. Acta Paediatrica Scandinavica, Suppl. 209.

Correspondence to Dr. H. H. Kaye, Children's Department, Newcastle General Hospital, Westgate Road, Newcastle upon Tyne NE4 6BE. 